\title{
Digital Tools in the System of Communication with the Client in the Market of Educational Services
}

\author{
Orlova M.V. ${ }^{*}$ Silina S.A. ${ }^{1}$ Aleksandrova I.Yu. ${ }^{2}$ \\ ${ }^{1}$ State University of Management, 109542, Moscow, Russia \\ 2 Russian State Agrarian University - Moscow Timiryazev Agricultural Academy (MTAA), 127550, Moscow, Russia \\ *Corresponding author.Email: rubinkaira35@mail.ru
}

\begin{abstract}
Special attention to building a system of marketing communications in the online environment is determined by the rapid development and growth of markets, as well as the variability of consumer preferences and the need to constantly maintain the process of interaction with customers. There are many modern marketing communication tools which, depending on the intensity and quality of use, can form an effective communication system. The article presents the results of the study summarizing the existing experience of using online and offline tools, on the basis of which the company can choose the tools that will form an effective communication system for interacting with consumers.
\end{abstract}

Keywords: marketing communications, language schools, online education market, high-tech tools, high-

hume tools

\section{INTRODUCTION}

In the context of global globalization, technological progress and high employment of residents of megacities, the need to translate the learning process into the Internet space is becoming increasingly obvious. The online education market as a whole, the so-called "EdTech market", has a steady growth trend. According to the data provided in the "Study of the Russian market of online education and educational technologies", initiated by Netology Group, FRII, High school of Economics, etc., $63 \%$ of people, for example, studying foreign languages, do it only online, and 37\% - combining it with other resources. According to Russian analysts, by 2021, $14 \%$ of the entire audience of additional professional education will switch to an online format. The online language learning segment is represented by online schools of one or more foreign languages; mobile and web applications, online simulators, services for finding an online tutor, and teachers engaged in private activities on the Network.

According to the same study, the potential of distance language learning in the market of educational services is quite large. In 2016, the share of the Russian language education market was 26.8 billion rubles, of which online language education accounted for $5.8 \%$ (1.55 billion rubles). In 2017-31 billion rubles, online-7\% (2.2 billion rubles); in 2018-minor changes in the entire market, online-10.7\% (3.3 billion rubles); forecast for $2021-24.6$ billion rubles, online - $15.9 \%$ (3.9 billion rubles). rubles): the market promises to shrink due to a decrease in the number of target audience (from 15 to 64 years) and the growth of the online part of the market, where the average fee for a lesson is significantly lower. In 2017 private business in the language training segment covered approximately $88 \%$ of the audience [1].

\subsection{Related Work}

The successful existence of an online educational company on the market is often based on a well-developed strategy of marketing communications. Marketing communications are a set of various informative methods and measures to influence the target audience in order to create or change the company's image, create awareness and commitment of consumers. The relevance and significance of communication strategy measures is confirmed by many experts and researchers, including F. Kotler, D. Jobber, Scott M. Davis, L. Rogers, and J. J. Keller. Trud, S. Fischer, V. I. Belyaev, G. Ya. Goldstein, V. E. Lankin, V. D. Markova, E. V. Popova, K. I. Terekhin, etc.

The second group of authors presents different points of view on the problem under discussion: digital marketing communications. Among them Fedorenko A. N., Ulyanovsky A.V. and others.

\subsection{Our Contribution}

The authors conducted a special study of foreign language schools that carry out their educational activities online and offline, as well as mixed-type schools. The paper presents the results of the study summarizing the existing experience of using online and offline tools, on the basis of which any language school can choose the tools that will 
form an effective communication system for interacting with consumers.

\subsection{Paper Structure}

The paper is organized in a following way. Section 2.1. presents the research, conducted by the authors. Russian language schools were investigated in order to identify the best marketing communication tools for online foreign language schools. Section 2.2. describes high-tech (new generation tools, including those related to active promotion on the Internet) and high-Hume (traditional) marketing communications tools. Finally, Section 3 concludes the paper and presents direction for future research.

\section{BACKGROUND}

\subsection{Research}

To identify the best marketing communication tools for online foreign language schools, the authors conducted a study of foreign language schools that operate both online and offline. In the course of the research, the following tasks were set: to identify the advantages of implementing educational activities in an online environment; to understand how the set and priority of the choice of marketing communication tools with the provision of online services changes. The study was conducted using surveys of participants in the educational process, the method of focus groups was used, and the representation of schools on the Internet was studied. 12 training centers and language schools of different learning formats were selected for the study: offline schools, mixed-type training centers, and online schools with interactive platforms. In addition, mixed learning centers were also divided into two subtypes: schools with standard offline services and online training on specialized platforms with applications and language simulators, as well as language centers that provide a Skype learning service (without a platform) in addition to the main set of full-time courses.

The study revealed that currently seven of the most popular language schools operate in a mixed format, providing offline and online services (Alibra School, BigWig, BKC-IH, English First, Star Talk, Language Link and Windsor), two training centers specialize only in fulltime classes (Wall Street English and Easy Speak), and three more schools conduct only online language training on interactive platforms - Skyeng, Englex and EnglishDom. Among mixed-format schools, Alibra School, English First, and Star Talk have special platforms and apps for online classes, while BigWig, BKC-IH, Language Link, and Windsor provide a foreign language learning service via Skype.
A survey of clients of foreign language schools showed that with an average basic set of services provided (courses and language programs), two-thirds of all respondents are interested in learning remotely, $45 \%$ of participants are guided solely by word of mouth and authoritative opinion, more than a quarter of respondents estimate the number of native language teachers and their qualifications. For $15 \%$, it is important to match the school's mission and message with their own ideas about the language learning process, and about $10 \%$ are able to be interested in the language center's offer, based on the degree of creativity, nonstandard advertising message and approach to learning. Some participants $(3 \%)$ are attracted by a well-organized, clear and beautiful language school website.

The online format for teaching foreign languages has a great potential for scaling. Since this is digital content, it can be used without loss of quality an unlimited number of times. Once you have developed a training course, you can replicate it with minimal additional intellectual and material costs. And if the course is accessible via the Internet, you can connect students and teachers from anywhere in the world, including native speakers [2].

In the online environment, the set and priority of choosing certain marketing communication tools for forming the process of interaction between the online language school and the target audience is changing, table 1. All schools use the following marketing communication tools, fig. 1 . The implementation of the communication strategy of online schools is carried out mainly through online technologies.

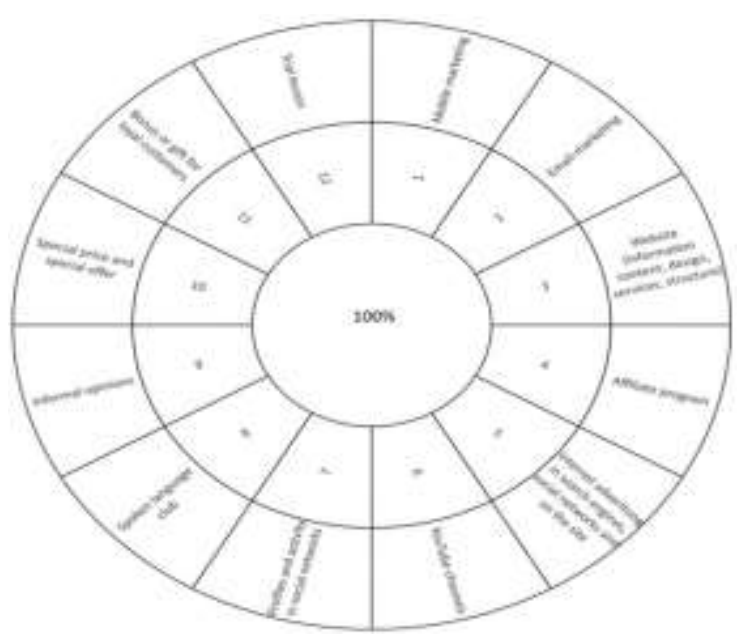

Figure 1 Use of marketing communication tools by language schools

Of all schools, 59\% use additional tools such as archetypal school image design; touch marketing; free additional services; brochures, flyers, coupons; invitations to school events; contests and games. 
Table 1 Use of additional marketing communication tools by language schools

\begin{tabular}{|c|c|c|c|c|}
\hline № & Marketing communications tools & Online schools & Offline schools & $\begin{array}{l}\text { mixed format } \\
\text { schools }\end{array}$ \\
\hline 1. & $\begin{array}{l}\text { Communities and interest groups (outside the } \\
\text { school's official social media pages) }\end{array}$ & $\begin{array}{c}\text { Skyeng } \\
\text { EnglishDom }\end{array}$ & - & BigWig \\
\hline 2. & Embedding in a language & Skyeng & $\begin{array}{l}\text { Wall Street } \\
\text { English }\end{array}$ & $\begin{array}{l}\text { Star Talk } \\
\text { Windsor }\end{array}$ \\
\hline 3. & The archetypal design of the image of the school & all & $\begin{array}{l}\text { Wall Street } \\
\text { English }\end{array}$ & $\begin{array}{c}\text { BigWig } \\
\text { BKC-IH } \\
\text { English First } \\
\text { Language Link }\end{array}$ \\
\hline 4. & Touch marketing & all & $\begin{array}{l}\text { Wall Street } \\
\text { English }\end{array}$ & $\begin{array}{c}\text { BigWig } \\
\text { BKC-IH } \\
\text { English First } \\
\text { Language Link } \\
\text { Star Talk } \\
\text { Windsor }\end{array}$ \\
\hline 5. & $\begin{array}{l}\text { Additional services are free of charge } \\
\text { (study materials, applications, library) }\end{array}$ & all & $\begin{array}{l}\text { Wall Street } \\
\text { English }\end{array}$ & $\begin{array}{c}\text { Alibra School } \\
\text { BigWig } \\
\text { BKC-IH } \\
\text { English First } \\
\text { Windsor }\end{array}$ \\
\hline 6. & Invitations to school events (courses) & all & $\begin{array}{l}\text { Wall Street } \\
\text { English }\end{array}$ & $\begin{array}{c}\text { Alibra School } \\
\text { BigWig } \\
\text { BKC-IH } \\
\text { English First } \\
\text { Star Talk } \\
\end{array}$ \\
\hline 7. & $\begin{array}{l}\text { Contests and games (outside of social networks and } \\
\text { not within the training course) }\end{array}$ & $\begin{array}{c}\text { Skyeng } \\
\text { EnglishDom }\end{array}$ & - & $\begin{array}{l}\text { BigWig } \\
\text { Windsor } \\
\text { Star Talk }\end{array}$ \\
\hline
\end{tabular}

For online language schools, almost all the main marketing communication tools are effective, except for invitations to private school events (the school's clients initially choose the online format in order to save time, so the school's face-to-face events are unlikely to be of great interest to them) and the distribution of printed products (its analogue for the online format is banner, viral, teaser advertising). If online schools of foreign languages have a mobile application for its promotion and popularization, the school actively uses mobile mailings with favorable offers and company promotions, as well as entertainment video and audio content in a foreign language and images with humorous captions - memes. All these actions form customer loyalty, creating a trusting relationship between the school's students and the company.

Website development and advertising on the Internet are used by language schools to increase site traffic and its popularity in search engines, and to increase audience awareness of the company. This creates a partnership with companies that have influence on the target audience of online schools, on their web sites is contextual advertising in search engines displayed media banners, viral or teaser advertisement, search is SEO-optimized for the top search queries, social media is actively targeted advertising. Online schools also create educational and entertainment channels on YouTube, and sometimes behave more aggressively, introducing pop-up banners (pop-UPS) on their web pages.

Creating an image of an online language school in accordance with an archetype allows the company to focus on a specific segment of the audience, set up relationships with users, broadcasting a bright and positive image of the brand, expressing its values in the design and content of the site.

Despite the high efficiency of the marketing efforts outlined above, word of mouth remains a key success factor in promoting such an online resource as an online language school, since when searching for a place to study, users primarily focus on reviews from friends and acquaintances, as well as on public opinions about a particular company posted on Internet forums and blogs.

Language schools are fully face-to-face learning format to a smaller value in the formation of effective interaction with customers has the appeal of the site design and the number of additional services outside of school courses (a large part of the marketing communication strategy implemented at the school, consequently, their effectiveness depends more on the situation, equipment and design space, rather than website design), while online content and schools of the mixed type website design platform, and the number and usability of services play a key role in attracting customers. 
Such a tool as language integration in a complex, more creative form is rarely used by both online and offline schools. In addition, a relatively small percentage of schools seek to increase the level of social activity and interactivity in the methodology, forming a community of students and introducing competitive and game-based events outside of their training courses. Thus, these marketing communication tools form the potential for further growth of many language schools.

\section{Section 2.2.}

In general, all marketing communications tools are divided into high-tech (new generation tools, including those related to active promotion on the Internet) and high-hume (traditional tools). Since online communication with the client is implemented through information technology, it is reasonable to assume that the promotion of online language schools is more influenced by high-tech tools. These include mobile marketing, web site, Internet advertising, email advertising, language integration, giving the worldview the desired shade of meaning through archetypes, giving the worldview the desired shade of meaning through beauty, touch marketing, and informal opinions [3]. Let's look at them in more detail.

Mobile marketing is an interactive marketing communication tool implemented using any mobile electronic device that supports SMS, GPRS, WAP, 3G. the Main advantage of this method of promotion is the ability to expand the advertising capabilities of other media through easy integration into the advertising campaign.

In marketing actively used SMS; MMS messages and can send and receive messages to the email address of the consumer, regardless of the technical capabilities of the telephone; interactive voice systems; ordering goods and services infomercials; chat applications for Dating and WAP technology, providing access to images, video and audio files, games, which can serve as prizes for participating in promotions. Also, when solving the problem of creating a brand commitment, you can create special brand images, Jingles for each promotion.

Among the features of mobile advertising, you can select not only information about a product or service, additional discounts or promotions, contests or announcements of company events, but also tests, consumer surveys, creating a series of commercials with interactive participation of customers or banner ads. Thus, the tool has a number of advantages, such as a wide audience coverage, interactive entertainment content, constant open access to information, and a relatively low cost of advertising.

Advertising on websites is one of the most important tools for business marketing communications on the Internet. Online business can be represented as an advertising business model (Ad-supported); a model that supports business that is conducted outside the network; a model for creating a new type of business, such as a web design Studio, or a model for increasing the project's capitalization [4].
A website as a set of information blocks and tools for interacting with one or more segments of the target audience depends on the chosen model and segmentation of consumers. The process of promoting a ready-made site involves a certain sequence of marketing and technological actions necessary to increase the popularity of the site when it is processed by search engines, and increase site traffic. The advantages of this marketing communication tool include sufficient cost-effectiveness of the method.

There are several types of advertising on the Internet: display advertising addressed to a mass audience (this includes dynamic or static banners, flash banners, pop-up Windows when opening or closing a web page); contextual, specialized advertising that affects a particular interested segment and serves as a source of additional information; search advertising that takes into account the text of the request, thereby segmenting the audience and creating demand, as well as advertising on thematic sites and subscription mailings.

Advertising on the Internet has a number of advantages: cost-effectiveness compared to television or print advertising, memorability and interactivity, wide citation and fairly clear targeting, since in addition to full-scale audience coverage, advertising has a targeted impact on target users. In addition, network advertising significantly speeds up the process of searching for a product or service through hyperlinks, which is a determining factor in increasing the level of sales, and can be placed in special virtual communities where target consumers of goods and services interact.

E-mailing is traditionally organized in two ways: by means of free mailing through the subscription form and on the basis of a special application. The main factors for the attractiveness of advertising in newsletters are high audience targeting due to thematic segmentation and the availability of detailed data about subscribers, and its high response when a message enters the field of users ' interests. A message in a newsletter can be a text or textand-image block, a banner, or a lowercase or targeted ad.

Among the strengths of this tool, it is noted that it is affordable and cost-effective, easy to inform subscribers (one of the greatest difficulties is associated with their retention), and the ability to select a target audience and get a high level of response from them.

Introduction language is a set of tools to increase the effectiveness of messages, and suggestive of linguistics (the science dealing with the study of the impact on the emotional background and the suggestion of using words and sounds), speech patterns (special of phrasing to manipulate: truisms, incomplete comparisons, illusions of choice, or inference, rhetorical questions, hidden commands, and presuppositions), reframing (game sense, change evaluation, reshuffle of positions, creation of new plants) and morphology (word plays and puns).

All of the above tools are used for selecting the most successful brand name, creating advertising articles, forming an emotional attitude, as well as in business and everyday communication, sales and creating creative advertising slogans. 
Giving a picture of the world the desired shade of meaning through archetypes and through beauty. The right archetype for the target audience translates certain images, character traits, and human aspirations, generating strong emotions and associations that have a psychological impact on the collective unconscious of consumers, further motivating them to make a purchase. The influence of archetypes on the subconscious is quite strong, so it is necessary to use this tool carefully, relying, in particular, on the "law on advertising", which regulates the use of images that affect the subconscious [5].

The influence of beauty as one of the ways to implement marketing communications is also very effective, as it has an aesthetic effect on the emotional background of a person. The effect of beauty is a subtle tool that, if used correctly and with high quality, can evoke a sense of pleasure and enjoyment in the consumer. This should be taken into account when choosing this method as a key one.

Sensory marketing works specifically on the senses, creating a clear Association of smells, sounds and melodies, colors with specific brands, causing positive emotions from brand interaction and the shopping process. The transfer of life experience related to the purchase and consumption of a product or service to the close environment is sometimes more effective than traditional advertising, enhancing its effect. However, it is necessary to draw a line between opinion, rumor and viral marketing, which are often combined in this method. Hearing is more informative and usually has a contrasting, appealing character and has a bright emotional color. A viral message is most often spam, designed to promote a product or service, get maximum attention and emotions from consumers by exceeding their expectations, providing gifts and additional services, refuting negative information about the product or original marketing move. "Word of mouth" is a spontaneous and large-scale process, but recently it is often created artificially to strengthen positions and increase demand for goods, which can negatively affect the brand image, since the exchange of opinions is primarily based on the reliability of information and the reliability of its source.

Online promotion tools used in foreign countries are also of interest for this study. According to the experts of the SEO Agency Rush Agency, $80 \%$ of the success of Google promotion in Western markets depends on external links. It is almost impossible to get to the top search site without external links, even with first-class expert content. Therefore, in the West, there is a whole industry and type of marketing - Link Building [7]. In the study of specialists of the crowd marketing system Reffer.ru a lot of attention is paid to building up the link mass, promoting through submittal sites with free registration, which can serve as site catalogs, job search sites, podcasts and video hosting sites, review sites, aggregators and document exchange sites, and mapping services [8].

Also as one of the main methods of promotion stands out the crowd-marketing: sharing links and posts, posting links on forums, social networks (for Russia it is mainly Facebook, YouTube and Instagram, for US - Facebook,
Instagram, Twitter, LinkedIn, to a lesser extent Google+ services with publishing of reviews, publication of articles in partnership on third-party sites whose audience includes or corresponds to the selected target segment. All these actions allow you to increase the traffic of the company's website, which means awareness, awareness and confidence in the brand [9].

To increase their position in search results, both Russian and Western companies often use local platforms and marketplaces. For Russia, this is a well-known Yandex.Market, Avito and PulsCen, for the US, for example, Amazon, Ebay or Bonanza, placing profiles on which companies further popularize their products and services [10]. It is also common to create satellite sites abroad - a network of auxiliary pages to support and promote the company's main site, which attracts additional traffic and increases brand awareness.

The price and importance of the client in the West is much higher than in Russia, so foreign companies tend to "surround" the user with their content after the first click, using retention-marketing strategies: making subscriptions to them and sending special offers by e-mail, placing ads with the product/service in social networks and on thirdparty sites, actively using high-quality pop-up Windows, online consultants and callback services, in order to focus the site visitor's attention on the product for as long as possible, fully demonstrating all its properties and advantages of purchase.

Thus, the methods and tools of promotion for Western and Russian companies, adjusted for the specifics of user preferences, are almost identical, due to the presence of common "laws" of existence in the Internet space, as well as existing guidelines in Russia for Western standards and principles of conducting online business.

Today, there are many different methods, tools and technologies for promoting online language schools both in the Internet space and in the main markets for goods and services. The choice of a particular marketing communication tool depends on the company's specific goals, budget, market situation, and the intended effect that the offered online educational service should have on consumers.

1. Introduction to the online language school: mobile and Email marketing, website (information content, design, services, structure), trial lesson, brochures, leaflets, coupons, archetypal design of the school image, touch marketing, informal opinions, Internet advertising in search engines, social networks and on the site, implementation in the language.

2. The main process: YouTube channels, profiles and activity in social networks, additional services for free (educational materials, applications, library), special price and special offer, partner programs.

3. Creating a commitment through engagement: a conversational language club, invitations to school events (not courses), contests and games (outside of social networks and not within the course), a bonus or gift for loyal customers, community and interest groups (outside of the school's official social media pages) 


\section{CONCLUSION}

Among the most effective high-tech communication tools for online language schools were the development of the company's website, the availability of additional services and platforms, active maintenance of social networks and creative Internet advertising, link building, the use of mobile mailings, the development of an archetypal brand image, as well as the management and control of informal opinions. From traditional methods of communication: special offers from the company, invitations to events or granting users any privileges, bonuses in the form of free lessons or access to paid content, as well as contests and online games, during which participants receive various additional opportunities for comfortable learning and motivating prizes.

Thus, there are many modern tools for marketing communications of language schools in the online environment, which, depending on the intensity and quality of use, can form a process of effective interaction with the client, improve the brand image, increase the popularity of the promoted service among Internet users, increase awareness of the company and expand the audience coverage, as well as form its trust and commitment to a specific brand in the market of online educational services. All these results will allow the company to develop strategy and gain a sustainable competitive advantage.

At the same time, it is necessary to mention that we should make a further research to understand how the choice of online communication tools depends on the age, habits, education of the students.

\section{ACKNOWLEDGMENT}

This work was supported by Department of service marketing and brand management of State university of management (Moscow).

\section{REFERENCES}

[1] Project " Research of the Russian market of online education and educational technologies " DOI: http://edumarket.digital

[2] Business education: how to switch to an online format DOI: https://uprav.ru/blog/203014/?utm_source=email_conte nt\&utm_medium=email\&utm_campaign=digest_5

[3] Ulyanovsky A.V. Marketing communications: 28 tools of the Millennium-Moscow: Eksmo, 2008. $453 \mathrm{p}$.
[4] Bokarev T. Encyclopedia of Internet advertising. - Moscow: Ed. Promo-ru house, 2000. $416 \mathrm{p}$.

[5] Federal law of the Russian Federation" on advertising " N 38-FZ of 13.03.2006, Article 5.

[6] Fedorenko A. N. Client community as a new way to promote companies / / online journal "science STUDIES". 2017. Volume 9, No. 5.

[7] Search engine promotion in Western markets: tips for business. // Internet marketing. — No. 2, 2018 DOI: $\quad$ https://www.rush-agency.ru/poiskovoeprodvizhenie-na-zapadnyh-rynkah-sovety-dliya-biznesa

[8] 10 top methods of promotion to the West. // pressfeed journalistic query service, 2015-2019 DOI: https://news.pressfeed.ru/10-topovyx-metodovprodvizheniya-na-zapad

[9] Promotion abroad: SEO guide in the Western market. // Project blog CyberMarketing.ru, 2012-2019 DOI: https://blog.cybermarketing.ru/prodvizhenie-zarubezhom-gajd-po-seo-na-zapadnom-rynke

[10] Marketing tools: from the classics to the latest. // Blog of LLC "sales Generator", 2019 DOI: https://sales-generator.ru/blog/instrumenty-marketinga/ 